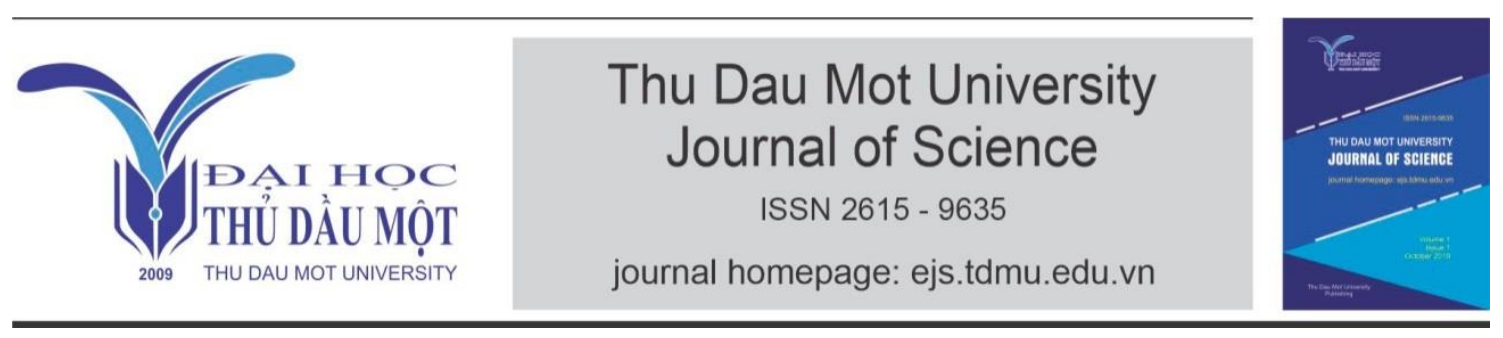

\title{
A discourse analysis about career and social status of the Vietnam working class: A case study from Binh Duong province, Vietnam
}

by Nguyen Quang Huy (Thu Dau Mot University)

Article Info: $\quad$ Received 11 Jan. 2021, Accepted 1 Mar. 2021, Available online 15 Mar. 2021 Corresponding author: huynq@tdmu.edu.vn

https://doi.org/10.37550/tdmu.EJS/2021.01.147

\begin{abstract}
In recent years, there have been more studies on the Vietnamese workers' life in the industrial zones. However, the research on career and social status of the workers is still a desert. This article investigates how Vietnamese workers perceive their career and social status. Data were collected through survey by quantitative questionnaire and in-depth interviews with 800 samples in industrial zones of Binh Duong Province of Vietnam. Finding results show that: (1) The workers evaluated their career and social status at an average level in compared to other classes in society. (2) With an average level, the voices of workers have not received adequate attention from the companies, government and unions when conflict of interest occurs. The workers' experience in daily social interaction is one of the reasons why workers perceive themselves in lower status than other classes in the social hierarchy. Further studies should be paid attention to individual experience through discourse to understanding the worker's life.
\end{abstract}

Keywords: discourse, career and social status, Vietnam working class, Binh Duong province

\section{Introduction}


The Vietnam working class appeared in Vietnam's situation is under rule of French colonialism (Dương Xuân Ngọc, 2014). Since its appearance, the Communist Party Vietnamese has identified the leading role of the working class in the resistance war against foreign aggression (Tran Phu, 1930). After the country was reunified, the working class has still played the role of leadership class of the Vietnam revolution to move forward socialism in social discourse. It is identified as the first labor force in building and defending country (Nghị quyết 20 - NQ/TW, 28/1/2008). However, in fact, the majority of Vietnam workers are nowadays come from the poor countryside and their life in industrial zones contain economic and social risks (Nguyễn Đức Lộc, 2013). The Vietnam working class's condition is still seen as the poor people immigrate to rich cities, in spite of their positive contributions to its economy. They contribute over $60 \%$ of total social product and $70 \%$ of the state budget per year (Đặng Ngọc Tùng cb., 2010). In the contradiction between the social discourse of the Vietnam working class and the situation of their life, the article have placed interest in the understanding the worker's own perceptions about their career and social status.

\section{Literature review}

Social status is the concept used to indicate position or rank, determined with honor or respect, of an individual or a group in society (Thye \& Witkowski, 2003). Social status not only identifies individual status but also relates to social distinction (Weber, 1946; Bourdieu, 1984). Individual will build their social identity by social status. From the point of view social status theory, it can be seen that the social status is always tied with certain qualities or values. However, this view is investigated by some post structuralists (such as Foucault, Lacan, Giddens, Goffman). For them, social status can become the object of power and manifest externally through validated texts or statements.

Discourse is an important concept in Michel's Foucault analysis of social history. Iara Lessa (2006) summarized Foucault's concept of discourse as "systems of thoughts composed of ideas, attitudes, courses of action, beliefs and practices that systematically construct the subjects and the worlds of which they speak". For Foucault, discourse is seen as a way to maintain and reproduce unequal structures in society. The composition of a discourse stems from a limited number of statements for which a set of conditions for existence [discourse] can be defined. Thus, discourse is a set of statements made up of historical value systems and expressed through different social practices (Foucault, 1972).

Like Foucault, other post structuralists are critical of the imposition of historical ideological discourses; on the other hand, they propose a multivocality approach to discourses of different subjects. Based on discourse theory, this article will analysis 
discourse from workers, representatives management, business owner...In multidimensional correlation, worker's voice should be seen as their behavior in the limited basic rights to achieve a better quality of life.

Discussing class struggle in society, Karl Marx (1844), on the stand of dialectical materialism, emphasized the alienation of the working class in two ways (1) Workers are who directly create products, but the products are owned by capitalists and (2) Worker's labor is exploited physically and mentally, however the value of their labor is not enough to create a reproduction of labor force. The proletariats are the workers in factories and they will lead the revolution against the bourgeoisie. According to Marx's point of view, the working class is the most alienation class in society and they will hold a central role in the revolutions leading to the socialism (Marx, 1844).

Along with Marx's view of the social conflict between the proletariat and bourgeoisie, Engels (1845) described the British of immigrant class in the mid-nineteenth century. According to Engels, the working class is representative of urban poverty. The working class poverty will soon lead to riots and revolts against the capitalism oppression and exploitation.

The studies of Marx and Engels are the first analysis of the working class socialpolitical status. In the view of Marx and Engels, the working class was pushed to the top of the social class. This point of view constitutes the power discourse of the working class and has influenced to the socialism countries.

Through the spread of Marxism into Vietnam, the concept of the working class's leading gradually became mainstream discourse. This is shown through the research works of Vietnamese authors such as "Xu hướng biến đổi giai cấp công nhân Việt Nam trong giai đoạn đẩy mạnh công nghiệp hóa, hiện đại hóa đất nuớc" by Dương Xuân Ngọc, 2005; "Thưc trạng của đội ngũ công nhân thành phố Hồ Chí Minh và giải pháp phát huy vai trò của đội ngũ này trong giai đoạn hiện nay” by Nguyễn Đăng Thành, 2007; "Sư biến đổi của co cấu giai cấp xã hội ở Việt Nam trong quá trình phát triển kinh tế nhiều thành phần theo định hướng xã hội chủ nghĩa" by Quản Văn Trung, 1999; Thưc trạng giai cấp công nhân Việt Nam hiện nay by Nguyễn Thị Quế and Nguyễn Thị Tuyết Hoa, 2008. Most authors focus on analyzing the Vietnam working class in two ways (1) The working class historical characteristic and (2) The leading role of the working class in the Vietnam revolution.

However, in recent years, there have been researches with new approaches such as social, economic, cultural life and workers are described as immigrant into large urban areas (Nguyễn Minh Hòa, 2005; Nghiêm Liên Hương, 2010; Lã Thị Thu Thủy và Nguyễn Phương Hoa, 2008; Huỳnh Thị Ngọc Tuyết, Nguyễn Thị Minh Châu, Đào Quang Bình, 2009; Trần Từ Vân Anh, 2009, Phạm Thanh Thôi, 2013). The main 
research direction of these topics is to focus on describing real life and analyzing working class difficulties. The diversity and richness of the new researches show a change in the perception of the working class position in Vietnam current society.

Although new researches in Vietnam have shown diversity approaches, however, these depict social life of workers without analysis on the career and social status of them in current period. Moreover, these are mainly based on statistics data survey. These have not been exploited deeply words, ideas or attitudes of workers. Therefore, this article will analyze of the workers' perception through conversations. In this way, we need to focus our attention on each individual's point of view, opinion and action rather than on constructing abstract concepts, which are common and far removed from the reality of life.

The article will use qualitative and quantitative methods. Quantitative research was conducted in four different locations in Binh Duong Province with 800 samples based on systematic random sampling (Di An town, Thuan An town, Ben Cat district, Tan Uyen district). Qualitative research was combined in - depth interviews with observation and participation with 30 samples. The sampling method is to select case study from different groups of workers (region, age, gender...). In addition, there were about 10 in - depth interviews with the representatives of management agencies in Binh Duong Province such as the Labor Confederation, the Women's Union, foreign invested enterprises, state owned enterprises...

\section{Findings and discussion.}

\section{Career and social status discourse}

In the contrast to the leading role of the working class in the pathway to industrialization and modernization in Vietnam by the state discourse (Nghị quyết 20 về giai cấp công nhân, Jan 2008), the workers have different thought about their career and social status. Through in depth-interviews data show that workers do not appreciate their role in social ladder system. A male worker said that the worker career is not appreciated in a society. It is just one the "common" career, which can be easily applied. "The worker career is never honorable. In social ladder system, it is an average level. Everyone can get a job in company." (H., male worker, 32 years old)

The readers are familiar with the structure and the text style in documents and resolutions on the working class will surely notice the difference in the way using the language of the state and the workers. In state discourse, the role of the working class is described as "leaders" or "pioneers", who have the ability to lead the revolution to success. However, the workers used the humility words when they talked about themselves. The male worker said that the worker career is "average" level in compared 
to other classes. The reason is because workers only meet to low standards of businesses, they are able to find a job in industrial areas. The government policies have built Vietnam as an FDI (Foreign Direct Investment) attractive place through cheap labor force. The average salary of Vietnam worker for one month is lower than some other countries in the region. According to statistics, the average salary per month of workers in Beijing (China) is 466 USD, triple at Hanoi is 145 USD (JETRO, 2012). Moreover, the other reason FDI invests in Vietnam easier than other countries because the term regulations in laws such as the law on environmental protection, law on taxation or protection policies for employees (Nguyễn Triều, 2009). On CIT (corporate income tax) tax incentives, new investment projects in extreme difficulty socioeconomic condition areas are enjoyed 10\% tax rate for 15 years, tax exemption for 4 years, reduction $50 \%$ in the next 9 years. In Thailand, investment projects in high investment incentives region enjoyed to CIT exemption for 8 years, not enjoyed to preferential tax rates (the CIT is $20 \%$ in Thailand). In Malaysia, high-tech investment projects are enjoyed to a tax free period of 10 to 15 years and are not enjoyed to preferential tax rates (the CIT is $25 \%$ in Malaysia) (Vũ Quốc Huy, 2015). The consequence is the employer's standards businesses are not only at a very low level but they also do not pay attention to improve the worker's life.

Labor recruitment criteria to work in industrial zones set by businesses are not too difficult and complicated. The survey data show the most important conditions for workers to be received in company are to meet health requirement. A male worker expressed his wish to me has good health to work and earn money to help his family.

"Wishing to be healthy, If I have a lot of money, I will go back home. But right now, I wish I had a good health." (H., male worker, 32 years old)

He continued to explain for the worker need to health and with an "elderly" (the word used by Mr H.) like him, it is very difficult to find a job. He commented his ability to find a job.

"It's difficult for me to find a job in my old age. I will try stay a here." (H., male worker, 32 years old)

In depth-interviews with workers over thirty years old, I found out concerns in their own words about the work uncertainty. Because businesses need to more labors now, finding a job in industrial zones is not too difficult, however, this is true for young worker. For the group of older workers, although they have working experiences, but their health no longer meet the job needs. Therefore, they do not find a job easily. A female worker, who has worked for more than ten years in Binh Duong companies, described about herself as "vegetables" or "grass" made me imagine worker's life weak and deciduous. 
"The workers are just like vegetables or grass. If it has good, it must be pick. The workers also must have a good health to work, but when they are old and weak, no one can do work here." (N.,female worker, 31 years old).

The quantitative data survey also found that the most problems for workers were low income and illness. There have $34.5 \%$ the workers choice low income and health were the most worried. Meanwhile, worry about unemployment accounted for $22.5 \%$ of workers's choice (see chart 1). The figure show the process industrialization development in Binh Duong Province has created many jobs. However, after a period of work time, health deterioration causes they could not prolong their work and low income made them unable to fully meet the cost of living in large industrial zones.

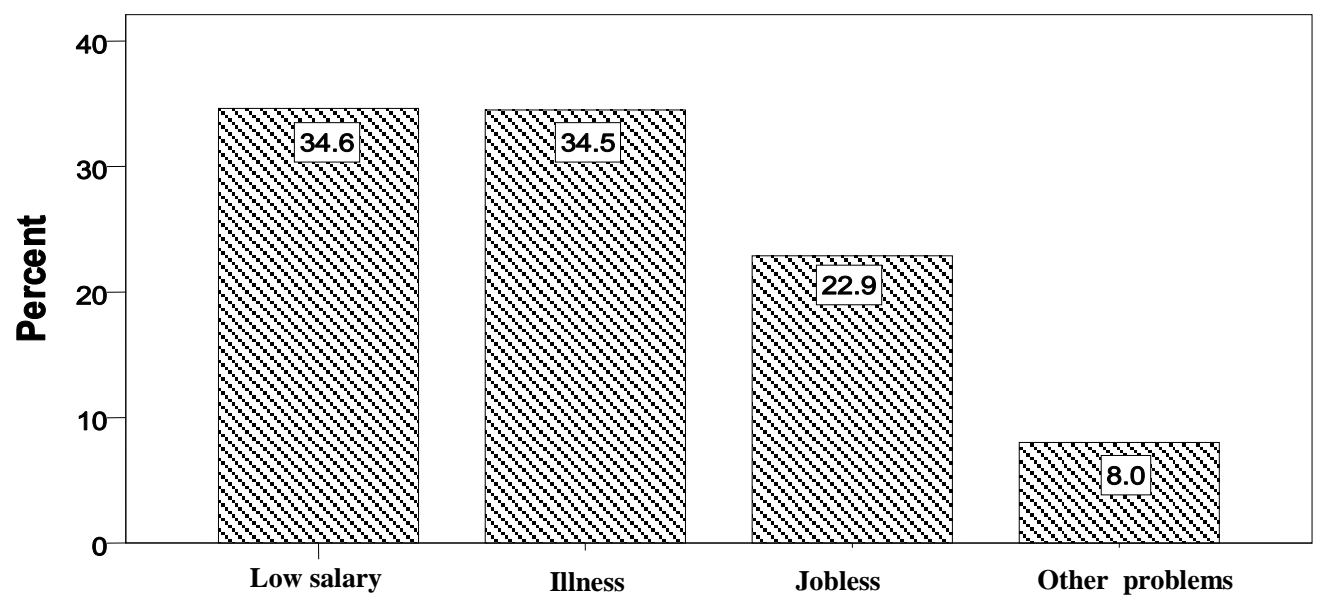

Figure 1. Worries of Workers

Besides health factor, other criteria such as education level, work experiences or technical skills are not important because the majority of workers in survey have the highest education level are grade 12 (accounting for 91.3\%) and there are very few workers before working in company have passed training courses (accounting for $77.4 \%$ ). In the case of employment, the worker will undergo a common training from one week to one month. Mr H. told us that when he went to the job interview, he did not have enough certificates but the company still accepted him. He was chosen as a worker by lucky not based on his ability.

"In interview, the interviewer asked me what I used to do, in fact I didn't have any jobs. I had just relied on fate and lucky. My documents were enough, just missing only certificates. They recruited 12th grade workers but I only had 9th grade degree. What can I do with grade 9? Then I spent one month training and have been employed." (H., male worker, 32 years old) 
The words that workers talked about their career such as lucky of fate reveal precarious and risky in their job search. In social system, certificate is as a role "social capital" for a find job, which also means that those who do not have it, will not be able to secure a job for themselves. In the race to find a job to make living in the city, workers only have health, are forced to working in industrial zones and they become the working class.

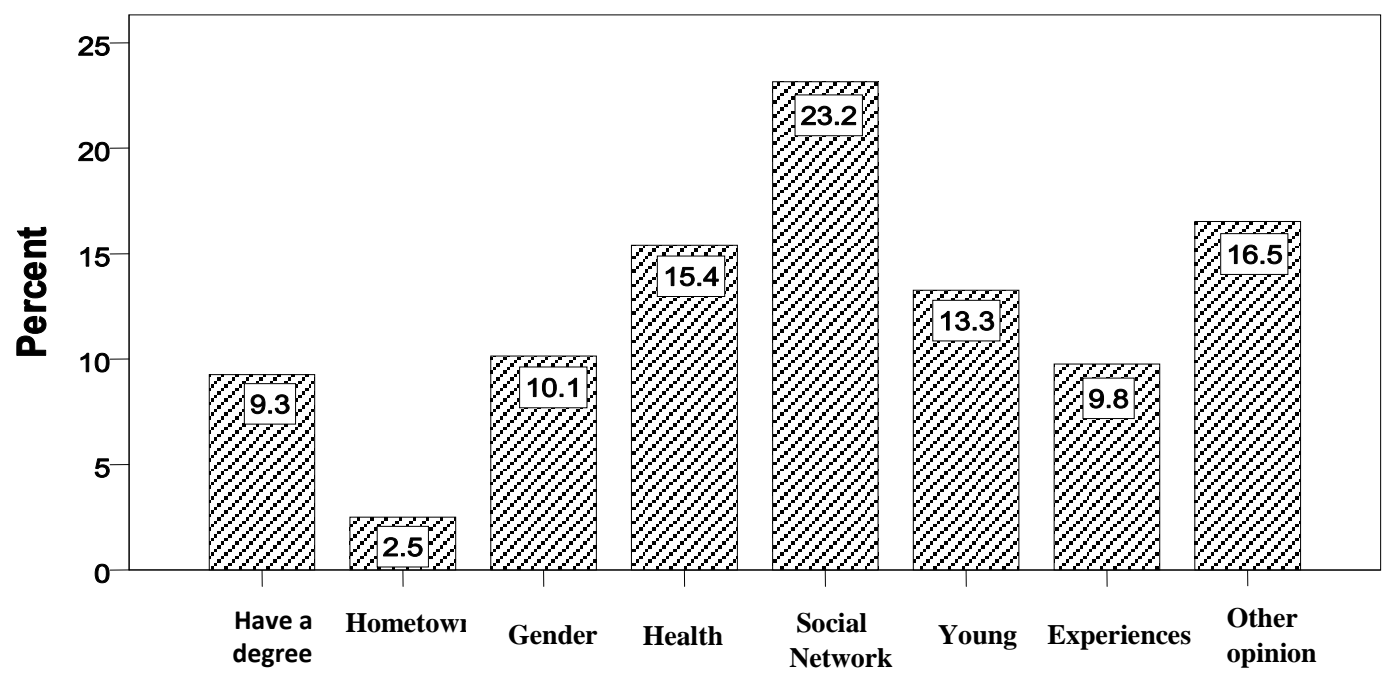

Figure2. Workers' advantage when applying a job

The quantitative data survey show the workers were evaluated three favorable factors when they applied for the job: social networks (accounting for 32.2\%), health (accounting for 15.4\%) and young (accounting for 13.3\%). Meanwhile, experience only accounting for $9.8 \%$ and professional certificate accounting for $9.3 \%$ (see chart 2). Another source of quantitative data show there was only $19 \%$ workers underwent training courses (see chart 3). The above data coincides with Mr H.'s thinking when I asked him what his perception is about the career, he said to me: "Selling health for living". For him, the worker is just an employee as a hired laborer by selling their own labor force in exchange for amount of money to sustain themselves and their family. When they no longer have enough health, they will return to their homeland with the little money they can save and then continue work as a farmer or find another job. The Mr H.'s thinking reminds us of the working class image more than a century ago in Engel's definition of a class that relies on selling health for a living (Engels, 1847: 8197).There is not much difference between Mr.H's thinking and Engel's definition. The workers are still the employees, who selling their labor to their employers. 


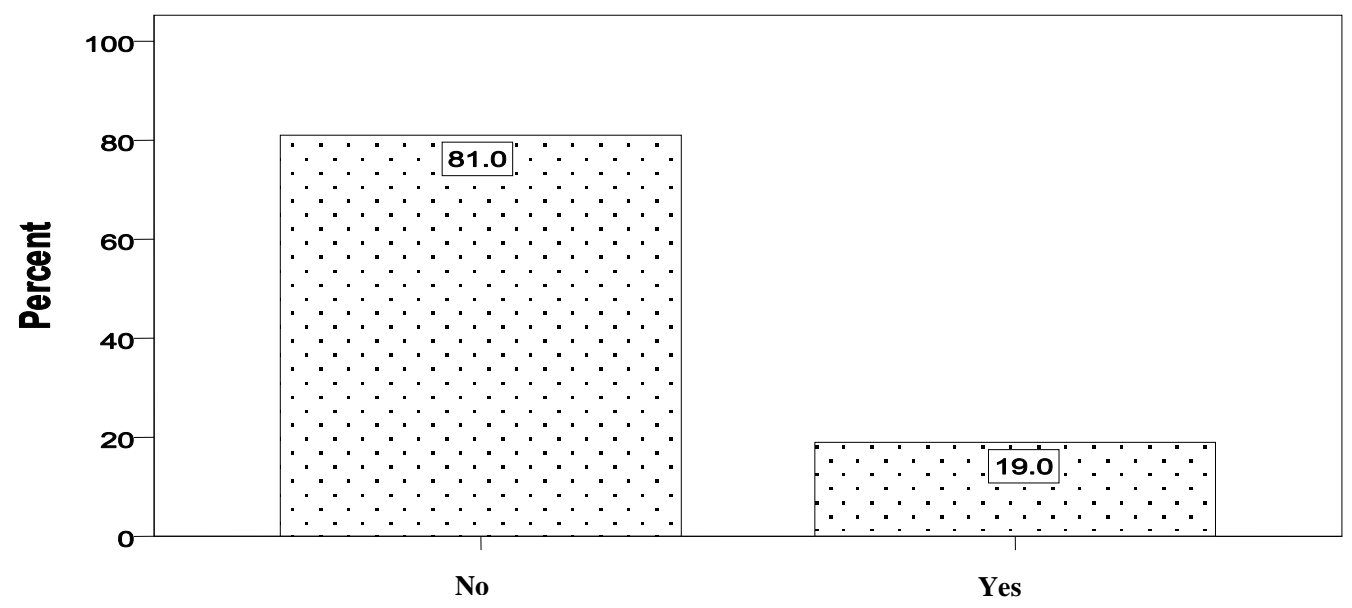

Figure 3. Career training for workers

In our in-depth interview data about the career of worker, there is an interesting conception from worker that "the career worker" is not like other careers in society. It is just labor working in company. As said that by Ms V., a worker female comes from a central province:

"Actually the worker is not a career. The career has to go to school to learn and practice then do something." (V., female worker, 23 years old).

In thinking of Ms.V, "career" is the word used to refer to those who are educated, have a degree and then go to work in company, while workers are employers who use their labor force to make a living tool. Whether this thinking can be explained from the traditional paradigm that is distinguished between intellectual labor and manual labor (Nguyễn Thị Lan, 2008) or it manifest a protest, rather an existential voice with the implication that see workers as miserable people, who face difficulties to make a living? Let me continue to the above question with the story about Ms V.'s complexity when she applied the job. Although she graduated from college in Saigon, she still good not find a job as her intention because she did not have enough experience as required of employer according to her explanation. She went to Binh Duong to found a job in company. She hoped that the job could make her a living and support the children who were still studying at home. She has started over a year and the impression of the small girl was the hard working life. When she was talking about the first time interview, she could easily find a job in the company but that day brought her a feeling of humiliation. "The team leader or superior think workers have very low education. Many people think workers have no thinking, just to do. So they have the attitude of cursing. When I heard these words, I felt sad. I have a degree but I was treated like that." (V., female worker, 23 years old). 
Humiliation feeling of Ms V. when she heard words from employer about workers such as no thinking, mindless...show bitter mood of being worker when she applied a job. Here these recruiting staff did not see workers as individuals with the need to find a job to make a living, they just saw workers as majority that they have to contact and communicate every day. The behavior of recruitment staff once again reminds us not to see people as abstract individuals separate from the reality of life, but to see them as the thoughtful and dignified individuals.

Continuing to discover about the experiences of the worker's status, I was told another story of female worker about her complexity when we talked about the worker career with other career. It started when she returned hometown, after nearly three years working at Binh Duong. In meeting classmates, she felt a complexity feeling when she saw her friends were now doing stable jobs. The climax of the story was pushed when she heard they talked about the joy in their career.

"In meeting classmates, they told to teach pupils, know this or that person. They just asked me why you still worked in factory." (N., female worker, 23 years old).

The obsession inferiority was still lingers on her during trip back to hometown. She continues with sad tone:

"My friend is a teacher. Everyone meets her on the street call the teacher. Meanwhile, everyone meets me just call the name." (N., female worker, 23 years old).

The inferior image of the worker is manifested by vocative in meetings with acquaintances. Respectful attitude of them with Ms N. friends and ignore attitude toward her shows the contempt of them or the career she was doing. Therefore, their voice do not hear social attention and as a result, they internalize the view of other people and see themselves as people of a under level of society.

From underestimating the role of the worker's career to their choosing social status is very low in social ladder system. Mr H. said that the social status of worker when I asked him:

"At the lowest level, If they [boss] curse, we must to listen. Then they said what we did not right. Sometimes the board of director invited us to meet them. They slapped the table and cursed workers." (H., male worker, 32 years old).

The quantitative data show the workers did not appreciate their social status. In the quantitative survey, we designed a hierarchical scale to compare social status of different classes. This scale consists of seven different classes (see table 1) and is scored one to seven point. One is the highest score corresponding to the highest status and seven is the lowest respectively with the lowest status in society. After adding all the point, we will work out the average for each class. The results that we have shown the workers rate their social status at position 5 . The three highest social status are state 
leaders (1.60), entrepreneurs (1.99) and state employees (2.92). In the opposite direction, the three lowest social status are belong to workers (5.15), farmers with close score (5.30) and unskilled labor (6.41). The middle position is the small business (4.63). The classification of workers shows that there is a contrast between workers (in low status) and managers (in high status). Workers, farmers or unskilled labor (lottery ticket sellers, motorbike riders...) are themselves perceived belonging to the lower classes of the social hierarchy. This rate contrast to state discourse that always upholds the role of the worker class. The worker's choice reflects relatively exactly the structure of power in Vietnamese society today. Rights holders power belong to classes of managers or state employees, while the workers, who are directly wealth and material for society, only has a very humblest status.

TABLE 1. Classes' social status in Vietnam society

\begin{tabular}{lccccc}
\hline \multirow{2}{*}{ Class } & \multicolumn{2}{c}{ Sample } & Average & $\begin{array}{c}\text { Standard } \\
\text { Deviation }\end{array}$ \\
\cline { 2 - 4 } & Value & Missing & & 1.99 & 1.043 \\
\hline Business & 800 & 0 & 5.30 & 1.239 \\
\hline Farmer & 800 & 0 & 1.60 & 1.016 \\
\hline State management & 800 & 0 & 2.92 & 0.852 \\
\hline Official & 800 & 0 & 4.63 & 1.047 \\
\hline Small businesss & 800 & 0 & 6.41 & 1.044 \\
\hline Simple labor (motor riders, sell lottery...) & 800 & 0 & 5.15 & 1.103 \\
\hline Worker & 800 & 0 & & \\
\hline
\end{tabular}

The remarkable statistics is the proportion of workers who are Vietnam Communist Party members. According to the Vietnam General Labor Union, currently only $1.2 \%$ of private enterprises, limited liability companies, joint stock companies and foreign direct investment enterprises have party branches, with the number of party members only equal to $0,84 \%$ of the total number of country. Especially, from 2000 up to now, the percentage of workers admitted to the Vietnam Communist Party has never been more than $10 \%$. According to data of the Central propaganda and training commission (2008): In 2003, the number of workers who are direct production admitted to the communist party accounts for $7.69 \%$ of the total number (10.723/143.550); in 2004, this rate was $8.19 \%(12.899 / 157.510)$ and in 2005, it was 6.87\% (11.646/169.461).

The low proportion of worker's Vietnam Communist Party members indicates the distribution of power in current Vietnam leadership system. In the leadership system, the proportion of workers involved in management is very low. Although in these state 
discourse affirm the working class leadership (resolution 20), but in reality this role of workers is very weak.

Workers' perceptions on their career show the difference in their consciousness with state discourse about their social status in the current context. Their experiences shaped in the interaction with the social environment also made them perceive themselves in a lower status than other classes in society. Whether with low social status, the voice of workers received adequate attention from the companies, government and unions when conflict of interest occurs or not will be the story that I will discuss below.

\section{Lack of dialogue}

If there was a fundamental existential right, it would have to be recognized by others as a human being. A true human being can freely express his or her feelings, thoughts and voices in the face of problems of living situations. Man is never in a passive state. He or she always actively seeks way to maintain its existence, in other words, he or she fights for him or her own existence and thereby admit from others. No one can write about the need to seek recognition from others over Jean Paul Sartre: "We are not lumps of clay, and what is important is not what people make of us but what we ourselves make of what they have made of us" (Sartre, 1963: 49). Sartre's statement confirms that an important thing in human relationships is rights freely express own needs and to be heard by others. Reflecting on Sartre's statement encourages me to question whether workers' voices are heard in dialogues with the companies or the government. $\mathrm{Mr} \mathrm{L}$ is an old male worker from Đồng Tháp Province. In 2005 year, he moved to Ho Chi Minh City to work as a mason. Then he moved to Bình Dương Province to work in a ceramic company. His family situation was very difficult. His youngest daughter was still a student and his two sons have not found a job to support themselves. The family depended on only him and an acre of field in the countryside. His appearance and the way of talking are bold a South Vietnam farmer. During the interview, he proved quite comfortable even when we talked about the relationship between worker and owner. According to him, this was often conflict. And when there was conflict, the voice of the workers is always weak side:

"Our workers do not have a voice, just dare to complain. We do not dare to speak up the company superiors." (Mr L., male worker, 41 years old)

He talked about the frustration of workers in his company about the regulations for the Lunar New Year:

"As the former manager allows workers to leave from 27. This year, the new manager forced to workers to work until 29. There was no problem with the workers from South Vietnam like me but the workers from North or Central Vietnam, they could not go to back hometown. They took two days to return. We were just complained but no one 
could speak up directly to manager. We have no voice." (Mr L., male worker, 41 years old)

For workers away from their hometown, Tet is a rare opportunity for them to reunite with their families, so the regulations of the company manager made them frustration. But this frustration only occurred within the worker's thoughts or spread within their daily conversation. It rarely became the topic of public discussion in the company because workers could not speak up against the board of director's decisions.

"In general, most of the workers have no rights. They cannot say anything." (Mr L., male worker, 41 years old)

In the quantitative data in survey, the two problems that workers most often complain about were the low salary not enough to pay the life cost and the poor quality of meals (see more chart 4). However when I asked: "Did you respond to the manager?". He answered that: "I did not dare to speak up with manager". Continuing the story of the conflict between workers and manager, Mr L. gave us an example about lunch in his company. For him, lunch is a very important meal because it helps workers regain their health after the hard work in morning. But in his company, lunch cannot meet needs to of the workers. He described the lunch in his company that each serving usually ranges from 10.000 VND- 15.000 VND for one person. It consisted three dishes: a savory dish (meat, fish...), a soup, a stir fry dish and rice. However, the meal quality did not receive the consent of workers when they said that there was very little food and it did not ensure nutrition for a working day.

"The rice is less because they sell it by portion. Workers could not protest because the manager signed with the canteen. They said that the food like that. Eating or not? We don't know what to do? If we don't eat, we will not to work." (Mr L., male worker, 41 years old )

Data collection from quantitative survey also support the above opinion. There were $44.6 \%$ workers said that the portion did not meet their nutrition needs. 


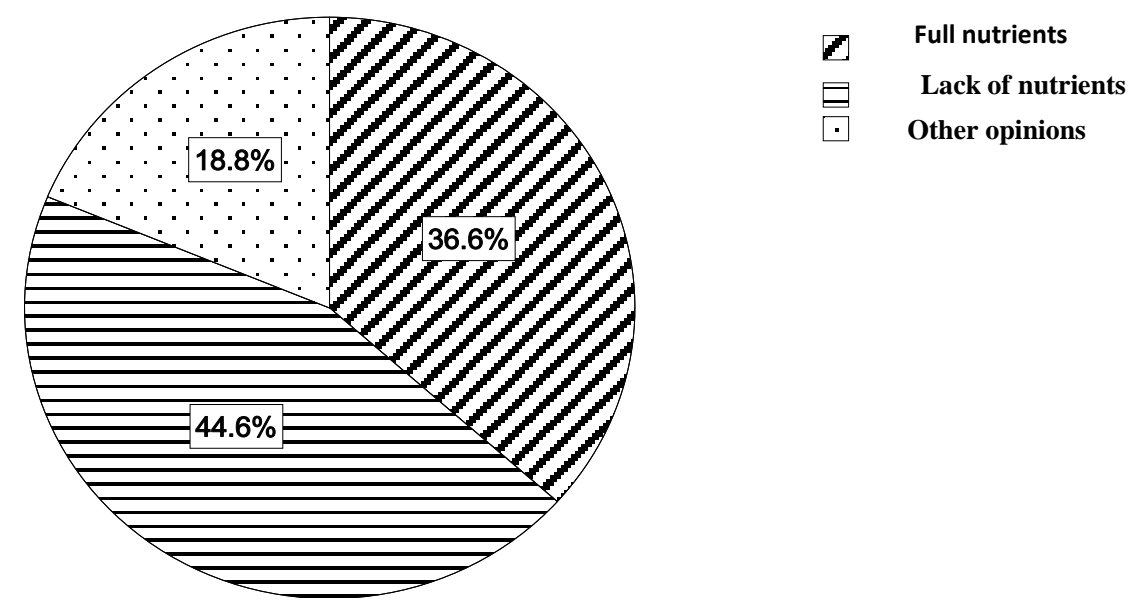

Figure 4. Workers' opinion on meal quality

However, when I asked what to do to improve the quality of their meals, most of workers said that they did nothing. There were $61.6 \%$ workers said that they did nothing to improve the quality of their meal in their company. It shows their resigned attitude. They could not speak out for a change. Another coping strategy was to cook rice or bought food at home (account for 13.3\%) in case the company's regulations are not strict. Feedback with the union only account for $14 \%$ worker choice and strike participation make up a small proportion $5.9 \%$. Workers also did not express directly their attitude to the manager. Most of workers chose silent as a solution. The explanation of workers is that they are "voiceless people". The worker hesitancy to face the manager is the reason that they dared not to speak out their problems. When the workers speak out strongly against injustice things, they face the risk of losing their jobs. 


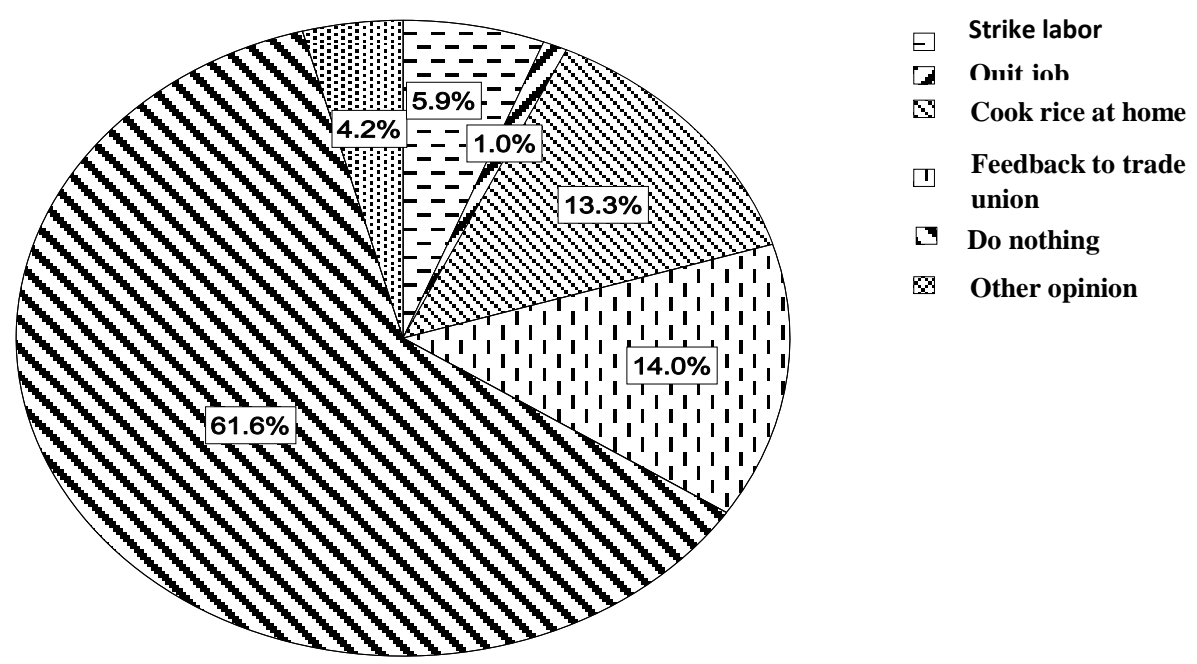

Figure 5. Worker's action to improve meal quality

A female worker, who has been working in a timber company for two years, told me about that her company kept the workers' Tet salary, which made workers very frustrated but they did not dare to respond. She said that in the company there are regulations on keeping workers' Tet salary to prevent they will not return. But she thinks most of workers disagree with this regulation. However, they could not speak out, because:

"Because of the people cannot make the money to pay for the family, so they are afraid of being fired." (Ms L., female worker)

The worker's limited voice is also correlated with ineffective management of local government. According to the workers, ineffective management of local government due to the lack of interest in worker's lives.

"The local government doesn't strict management with the companies. It abuses the labor force of worker but they rarely intervene." (L., female worker)

At another level of management is the union organization, which is seen as representing worker's voice, but as Mr M.Q.T said the union's role is limited due to the space gap. When the union is usually not located near industrial zones.

"There is only labor union but it is far away. If I want to go there, it will take me a lot of time."

Through our research, the trade union also falls into a "passive" position in resolving conflicts of interest between company and worker. Trade union intervenes when there are signs of strike of workers, in other words, they only get involved when disputes between company and worker become so intense that they cannot be reconciled. The 
trade union often settles in the direction of reconciliation between company and worker. Mr H., representing the labor union, answered us methodically about the role and duty of the trade union when handling the strike of workers.

"The task of trade union is not to let the strike of workers break out. If it happens, there are two ways: Firstly, we claim the company meets interest of the workers. Secondly, if it beyond the resolve authority of us, we will inform the federation. They go to discuss the problem with company to solve".

The role of trade union was emphasized by $\mathrm{Mr} \mathrm{H}$. as the mediator between stakeholders. However, in my opinion, the root of the problem is not that the trade union acts as an intermediary in dispute resolution but the role of the trade union should be understand the mind and aspiration of workers. In fact, this aspect seems to rarely have attended from trade union and other organization. Through conservation with worker's representatives, we recognized a pattern work style. Mrs T., who is working currently at the women union, shared us about her conciliation work. She told us about the conciliation the strike of workers at the company. The solution is usually told workers and then she persuades them to return to work. Like the trade union, the women union only stands out to reconcile the conflict between workers and company when the strike of workers happened. However, they don't pay attention to conflict in everyday that lead to strikes.

According to the workers, the biggest limit of the trade union is the little attention to worker's opinion. As Ms L. said about giving Tet gifts to workers. According to her, the Tet gifts for workers must be based on their actual needs. Her opinion is that the trade union in her company should buy foods that are practical worker's live such as cooking oil or MSG, but this was not heard by the trade union. Instead, she received cans of swallow water, which in her judgment was not delicious.

"My trade union is very bad. They don't defend the workers. Like Tet gifts, they ask team leader's opinion what gifts gave they the workers this year but when the team leader replied that the workers would to receive cooking oil or MSG, they said workers had all these things. Finally, they gave swallow water but it was not delicious."

Business judge similarly worker's point of view when they think that trade union only play a supporting role in worker's lives when they are facing difficulties. According to them, the trade union in the company is only formality. It doesn't not take real benefits to workers. When we were asked if it was really necessary to establish a trade union in company, Mr. V, Head of human resource in FDI business, told frankly with us:

"The law requires trade union checks social security and represent worker but it's just a formality. While the employer pays the union's salary." 
He concluded about the role of trade union just to "pay a fee". Then when we continued to question whether the worker's rights were really guaranteed without support from the union, he replied workers work to earn income to help themselves and family but rarely interested in participating in other social activities. When their benefits are guaranteed, workers do not need them trade union.

"Workers go to work to earn income. If they have unsatisfied income, they need allowance, other income or the union must support them."

However, from the union's perspective, Mr K., who represents for the confederation labor, told us the reason why the trade union are difficult to establish in businesses is that the presence of the trade union in the company give workers more voice. Moreover, it will increase understanding of laws for workers, thereby leading to business need to ensure more compliance with laws. According to him, most of the strikes of worker are caused by the business does not meet the employee's rights in term of salary and working regime. Business are dissatisfied when trade union provide legal support to workers as well as help them propose recommendations to authorities. Therefore, businesses are often "listless" and do not facilitate for the trade union.

"In the past, many workers only knew how to work. They were not less demanded because they did not understand laws. When they more understood laws, they demanded the trade union to intervene. The business must to response laws for employees."

During interviews with union organizations and businesses, we found that they avoided directly answering questions whether they actually listened to worker's voice. The limitation in the workers' voice partly explains the conflict between the worker discourse and the state discourse about their position as mentioned above. Their voices do not receive positive feedback from leaders. Organizations represents worker such as the trade unions or women unions do not go into real world to listen their voice. It is for this reason workers lose trust in social organizations.

Moreover, I realized behind the material poverty life is an extremely rich and complex inner world of the worker. Entered into their life world and established relationship with them, I felt that they opened to share opinions and feelings about problems in their life. Therefore, if we touch existential problems in real life of workers, we will create a close dialogue space. Then we can see on the other side of workers is human workers (human being) thinking and acting for their life. This suggests an approach that requires us to see workers as existences in their life world rather than as objects that exist in abstract categories. "The most current of such transformations occurs in storytelling and generally in artistic transposition of individual experiences." (Hannah Areandt, 1958:50). Arendt's statement reminds us to pay more attention to storytelling and experience's individual rather than grand narratives. 


\section{Conclusion}

Since the birth of the Vietnamese Communist Party under the influence of Marxism Lenin has attached the role of the working class to a historic mission as the main force and leading class of the revolution for national liberation and move on socialism. Despite going through many historical periods with different missions and objectives, the working class is still defaulted in official state discourse as a leading force to fight, defend and build the country. However, in contrast to the historical ideological discourse of the state, the survey data actually show that the workers did not appreciate their career and social status. They talked themselves by words such as: plants, vegetables, machines...etc. partly reflects the actual image of workers in industrial zones. All of above words are the discourse that reflects the living world of individual and thereby portrays a part of the immigrant workers. They are poor people in the countryside. For different reasons, they choose the big cities to seek opportunities to change their fate.

From the perceptions of workers about the career and social status, it is shown the difference with state discourse about the social position of the working class. Workers' experience in daily interactions with other individuals is one of the reasons that workers perceive themselves as a lower social status than other career in the system social hierarchy. Consequently, workers discourse shows a contradictory image of workers' perceptions of the state discourse that has been "theatricalization" of the state as analyzed by James Scott (1985) of a positive image of the role and social status of the working class. This different in another point of view stems from the fact that the state discourse has been encoded in an economic - political framework of thinking which is dominated by historical value systems and thus frame workers in fix social roles and positions. As a result, the state discourse missed out the voice of the workers coming from their real life circumstances.

1. See more Nguyễn Đức Lộc's analysis in his article Hiện trạng tiếp cận mức độ phúc lợi xã hội của công nhân tỉnh Bình Dương và đề xuất mô hình hợp lý, pp.65 in Đời sống xã hội Việt Nam đương đại (2015). Based on worker's income per month, Lộc divided into five groups. The poorest group has an income of 800.000VND - 2.510.000VND (accounting for 21.3\%), the second group has an income of 2.510.000VND - 3.000.000VND (accounting for 18.9\%), the third group has an income of 3.004.000VND - 3.500.000VND (accounting for 20.8\%), the fourth group has an income of 3.510.000VND - 3.998.500VND (accounting for 18.5\%) and the group has highest income over 4.000.000VND (accounting for 20.6\%).

\section{Reference}

Arendt, H. (1958). The Human Condition. Second Edition. Chicago \& London: NXB The University of Chicago Press.

Bourdieu, P. (1972). Outline of a Theory of Practice. Cambridge University Press. 
Đặng Ngọc Tùng (chủ biên). 2010. Xây dụng giai cấp công nhân Việt Nam giai đoạn 2011 2020. NXB Lao động.

Dương Xuân Ngọc. Luận bàn về giai cấp công nhân Việt Nam hiện đại - đặc điểm và sú mệnh lịch sủ của nó. Nguồn: http://www.mattran.org.vn/home/TapChi/so\%2046/ diendanddkdt1.htm\#. Truy cập ngày 10/11/2020.

Engels, F. (1994). Tình cảnh giai cấp công nhân Anh. In trong Các Mác và Ph. Ăngghen toàn tập. Hanoi: NXB Chính trị Quốc gia.

Engels, F.(1969). Nhũng nguyên lý của chủ nghĩa cộng sản (The Principles of Communism). Paul Sweezy dịch. Selected Works. Volume 1. pp 81-97. Progress publisher Moscow.

Foucault, M. (1972). The Archaeology of Knowledge. Translated by A. M. Sheridan Smith. New York: Pantheon.

Foucault, M. (1974). Madness and Civilization. Bản dịch của Richard Howard. Vintage. Ân bản $1,1988$.

Huỳnh Thị Ngọc Tuyết, Nguyễn Thị Minh Châu, Đào Quang Bình (2010). Mạng lưới xã hội của công nhân nhập cư ở khu công nghiệp Biên Hòa. Tạp chí Khoa học Xã hội số 5, tr. 29 $-38,2010$.

Lã Thị Thu Thủy (chủ biên). 2011. Thay đổi tâm lý của thanh niên công nhân xuất thân tù̀ nông thôn. NXB Khoa học Xã hội.

Lessa, I. (2006). Discursive struggles within social welfare: restaging teen motherhood. British Journal of social work 36.

Marx, K. (1994). Bản thảo kinh tế học - triết học năm 1844. In trong Các Mác và Ph. Ăngghen toàn tập. NXB Chính trị quốc gia,

Nghị quyết 20-NQ/TW. 28/1/2008. Hội nghị lần thứ sáu Ban Chấp hành Trung ương khóa X.

Nghiêm Liên Hương. 2010. Tính liên tục của nông thôn - thành thị: Cuộc sống của công nhân may di cư tại Hà Nội, tr.289-306, trong Hiện đại và động thái của truyền thống ở Việt Nam: Nhũng cách tiếp cận Nhân học. Quyển 1. NXB Đại học Quốc gia TP. Hồ Chí Minh.

Nguyễn Đức Lộc. Hiện trạng tiếp cận mức độ phúc lợi xã hội của công nhân tỉnh Bình Dưong và đề xuất mô hình hợp lý. Đề tài Khoa học Công nghệ tỉnh Bình Dương, 2011-2013.

Nguyễn Minh Hòa. 2005. Vai trò của tổ chức trong việc chăm lo đời sống văn hóa tinh thần trong các khu công nghiệp tập trung tại TP. HCM. Kỷ yếu Hội thảo khoa học Đời sống văn hóa tinh thần của công nhân tại các KCN - KCX TPHCM, 12/2005.

Nguyễn Thị Lan. Về dự định nghề nghiệp cho con của các bậc cha mẹ trong bối cảnh phát triển kinh tế tư nhân ở nước ta. Tạp chí Tâm lý học. Số 3 (108), 2008.

Nguyễn Triều. 2009. Sông Thị Vải bị ô nhiễm: Vedan góp 90\%. Đăng ngày 8/12/2009 trên báo Tuổi trẻ. Nguồn: http:// tuoitre.vn/tin/chinh-tri-xa-hoi/20091208/song-thi-vai-bi-onhiemvedan-gop-90/351986.html. Truy cập ngày 10/11/2020.

Phạm Thanh Thôi. 2013. Đời sống xã hội của thanh niên nhập cư lao động phổ thông tại các cơ sở sản xuất nhỏ ở TP. Hồ Chí Minh. Tạp chí Khoa học Truoòng Đại học Mở Tp.Hcm - số 5 (33), tr. 95-107, 2013.

Sartre, J.P. 1956. Being and Nothingness an essay on phenomenological ontology. Dịch và giới thiệu bởi by Hazel E. Barnes. NXB Philosophical library New York. 
Sartre, J.P. 1963. Saint Genet: Actor and Martyr. Dịch bởi Bernard Frechtman. NXB New York George Braziller.

Scott, J. 1985. Weapons of the Weak: Everyday of Peasants Resistance, Yale University Press.

Thye, S. \& Witkowski, C. 2003. The Status Value Theory of Power: The Effect of Status and Resource Differentiation on Power in Exchange. Presented at the Annual Meetings of the American Sociological Association, Atlanta, GA.

Trần Phú. 1930. Dụ thảo luận cuoong chính trị. www. tapchicongsan.org

Trần Tử Vân Anh (2009). Nghiên cưu quan niệm của công nhân về quyền đình công, nghiên cưu điển hình 20 công nhân tại hai công ty ở quận Thủ Đức TP. HCM (Luận văn Thạc sĩ ). Trường ĐH KHXH\&NV TP. HCM.

Vũ Quốc Huy (2015). Thu hút đầu tu nước ngoài tại Thái Lan, Malaysia và kinh nghiệm cho Việt Nam. Đăng ngày 27/3/2015 trên website khucongnghiep.com.vn. Nguồn: http:// khucongnghiep.com.vn/tabid/68/articletype/ArticleView/ articleId/1247/default.aspx. Truy cập ngày 10/11/2020.

Weber, Max. (1946). From Max Weber: Essays in Sociology. Edited, translated, and with an introduction by H. H. Gerth and C. Wright Mills. Taylor \& Francis. 2007. 